\title{
PRODUKTIVITAS DAN BIAYA PRODUKSI PENEBANGAN HUTAN TANAMAN INDUSTRI DI PT INHUTANI II PULAU LAUT
}

\author{
(Productivity and Cost of Felling Plantation Forest in PT Inbutani II \\ Pulau Laut)
}

\author{
Oleh/By: \\ Marolop Sinaga
}

\begin{abstract}
The research of felling plantation forest was carried out in forest area of PT Inhutani II, Semaras, Pulau Laut, South Kalimantan which has the plantation of mangium (Acacia mangium). The felling system used was clear felling with the sample of 97 trees. In felling the trees, the small type chainsaw was used and the lowest possible cutting was practiced. The objective is to find the productivity and cost of forest plantation felling. The results show that the productivity of felling is around $0.738-11.645$ $\mathrm{m}^{3} /$ hour with the average of $3.12 \mathrm{~m}^{3} /$ hour. The barvesting production cost is around Rp 814 . $R p 18,868 / \mathrm{m}^{3}$ with the average of $R p 4,411 / \mathrm{m}^{3}$. It is still possible to increase the productivity by improving workers skill.
\end{abstract}

Keywords: Plantation forest, productivity, felling cost.

\section{ABSTRAK}

Penelitian penebangan hutan tanaman industri telah dilaksanakan di areal hutan tanaman industri PT Inhutani II Semaras, Pulau Laut. Jenis pohon yang ditebang adalah mangium (Acacia mangium). Penebangan dilakukan dengan sistim tebang habis sesuai dengan tujuan pengusahaan hutan tanaman industri, sehingga contoh uji yang diamati terdiri dari 97 pohon. Perlakuan dalam penelitian ini yaitu penebangan dilakukan dengan meninggalkan tunggak serendah mungkin, dan menggunakan gergaji rantai berukuran kecil mengingat diameter pohon yang kecil tidak seperti diameter pohon pada hutan alam. Tujuan penelitian adalah untuk mengetahui produktivitas dan biaya produksi penebangan hutan tanaman industri. Hasil penelitian menunjukkan bahwa produktivitas penebangan berkisar antara $0,738-11,645 \mathrm{~m}^{3} / \mathrm{jam}$ dengan rata-rata $3,12 \mathrm{~m}^{3} / \mathrm{jam}$. Besarnya biaya penebangan berkisar antara $R p 814 / \mathrm{m}^{3}-\mathrm{Rp} 18.868 / \mathrm{m}^{3}$ dengan rata-rata Rp. $4.411 / \mathrm{m}^{3}$. Produktivitas penebangan dapat ditingkatkan dengan mengefisienkan waktu kerja dan apabila produktivitas meningkat maka biaya produksi penebangan dapat diperkecil sehingga lebih murah. Untuk itu keterampilan para pekerja penebang pohon perlu ditingkatkan sehingga dapat menggunakan waktu seefektif mungkin.

Kata kunci: Hutan tanaman industri, produktivitas, biaya penebangan. 


\section{PENDAHULUAN}

Pemanenan atau pemungutan hutan merupakan istilah yang biasa dipakai di kehutanan yang meliputi kegiatan penebangan pohon termasuk di dalamnya pemotongan/pembagian batang pohon, penyaradan, pengangkutan dan muat-bongkar kayu. Staaf dan Wiksten (1984) menyatakan bahwa ada tiga hal yang perlu dipertimbangkan dalam kegiatan pemanenan hutan agar biaya pengeluaran kayu relatif rendah. Tiga hal tersebut adalah (1) pilihan cara mekanisasi, (2) pilihan waktu pemanenan dan (3) pemusatan teknik operasi pemanenan pada waktu dan ruang yang tepat. Untuk mempersiapkan pelaksanaan pemanenan hutan dengan sebaik-baiknya, diperlukan informasi tentang potensi hutan dan kondisi lapangan di mana informasi ini dapat diperoleh antara lain dari foto udara dan atau citra satelit yang didukung dengan peta topografi, peta geologi, peta tanah, peta meteorologi dan peta vegetasi. Melalui media tersebut dapat direncanakan jaringan jalan hutan, bentuk dan luas petak tebangan, inventarisasi potensi, tempat pengumpulan kayu, kemah basis dan berbagai rencana lainnya.

Kegiatan pemanenan kayu di hutan tanaman industri telah dilakukan di PT Inhutani II Pulau Laut di mana dimensi pohon yang dipungut jauh lebih kecil dibanding dimensi pohon yang ditebang di hutan alam. Dalam praktek pemanenan hutan tanaman industri di lapangan ternyata menghadapi masalah teknis dan non teknis.

Masalah teknis yang perlu mendapat perhatian lebih lanjut antara lain adalah masalah penebangan di mana dalam prakteknya masih dijumpai adanya tunggak-tunggak pohon yang cukup tinggi sehingga terjadi pemborosan sumber daya hutan. Hal ini dapat juga disebabkan oleh ukuran gergaji rantai yang digunakan untuk menebang adalah gergaji rantai yang ukurannya terlalu besar sebagaimana dipergunakan dalam penebangan hutan alam. Untuk itu teknik penebangan dengan tunggak serendah mungkin perlu diimplementasikan. Penebangan sebaiknya dilakukan dengan aturan/prosedur, antara lain penentuan arah rebah, pembuatan takik rebah dan takik balas. Kedalaman takik rebah berkisar 1/3 - 1/4 diameter pohon yang ditebang dengan sudut kemiringan 45 derajat. Sedangkan takik balas dibuat dengan ketinggian 1/10 diameter pohon di atas permukaan takik rebah. Dikaitkan dengan cara penyaradan kayu ke pinggir jalan angkutan, maka arah rebah pohon dapat dikelompokkan dalam tiga macam yaitu arah sejajar, tegak lurus dan miring dengan arah jalan sarad.

Masalah non teknis yang dihadapi antara lain disebabkan masalah budaya kerja tenaga pemanenan hutan dan semangat untuk melaksanakan aturan kerja yang telah ditetapkan. Sistem pengupahan secara borongan juga menyebabkan para pekerja kurang perduli terhadap mutu praktek pemanenan pohon, misalnya tunggak pohon yang ditinggal di atas permukaan tanah $(20-40 \mathrm{~cm})$ atau kayu dengan diameter $20 \mathrm{~cm}$ masih banyak ditinggalkan di hutan atau tempat penebangan. Demikian juga banyak pohon yang rusak akibat kurang tepatnya melaksanakan teknik penebangan pohon. Teknik penebangan yang diterapkan oleh operator gergaji rantai atau penebang pada umumnya hanya berdasarkan atas kebiasaan dan kemudahan bekerja tanpa memperhatikan petunjuk kerja. Kesalahan yang umum dilakukan adalah pembuatan takik rebah maupun takik balas dan cara memotong batang pohon yang semuanya dapat mengakibatkan pemborosan kayu maupun menimbulkan kecelakaan. 
Sastrodimedjo et al. (1972) mengemukakan bahwa kesalahan bentuk takik rebah dan takik balas maupun ketentuan yang tidak diikuti dapat mengakibatkan arah rebah yang tidak tepat, penurunan kualitas, pemborosan kayu juga pemborosan waktu dan tenaga bahkan dapat menimbulkan kecelakaan. Beberapa kesalahan umum dalam penebangan antara lain : (1) takik rebah terlalu tinggi dan tidak datar (berbentuk V) mengakibatkan arah rebah tidak tepat sebagaimana diharapkan, (2) takik rebah terlalu tinggi dan terlalu besar, mengakibatkan pemborosan kayu dan tenaga, (3) takik rebah belum selesai [cukup] langsung dibuat takik balas yang mengakibatkan arah rebah tidak menentu dan (4) takik rebah keliru pada banir dapat menimbulkan bahaya bagi penebang. Sedangkan kesalahan dalam pembuatan takik balas antara lain : kedudukannya miring, lebih rendah atau sama tinggi dengan takik rebah yang dapat mengakibatkan rebahnya pohon membalik sehingga membahayakan, Beberapa hasil penelitian oleh Sastrodimedjo \& Simarmata (1978), Sinaga dan Thaib (1982) dan Simarmata \& Dulsalam (1985 a dan 1985 b) menunjukkan bahwa besarnya tingkat efisiensi pemanfaatan kayu baru mencapai kurang lebih $80 \%$.

Hal ini berarti jumlah bagian pohon yang tidak dimanfaatkan yang menunjukkan pemborosan sumber daya hutan sekitar $20 \%$. Limbah sebesar $20 \%$ ini terdiri dari limbah tunggak 3\%, limbah batang 17\%. Dengan demikian jumlah keseluruhan limbah penebangan menjadi cukup besar sehingga jumlah kayu yang benar-benar dimanfaatkan akan menjadi lebih kecil dari potensi harapan.

Bertolak dari permasalahan penebangan tersebut telah diadakan penelitian penebangan di hutan tanam industri PT Inhutani II Pulau Laut dengan tujuan untuk mengetahui dan sekaligus memperbaiki teknik penebangan untuk meningkatkan intensitas pemanfaatan pohon. Sasaran penelitian adalah mengamati perlakuan dalam penebangan sehingga tersedia teknik penebangan yang efisien dan efektif yang dapat dijadikan sebagai pedoman bagi perusahaan dalam meningkatkan kinerja perusahaan dan kesejahteraan masyarakat di sekitar hutan.

\section{METODE PENELITIAN}

\section{A. Lokasi dan Waktu Penelitian}

Penelitian dilakukan di areal hutan tanaman industri PT Inhutani II, kelompok hutan Pulau Laut, Daerah Hutan Semaras, Cabang Dinas Kehutanan Kota Baru, Dinas Kehutanan Provinsi Kalimantan. Selatan pada bulan Desember 1999 sampai bulan Januari 2000. Keadaan topografi lapangan relatif datar.

\section{B. Bahan dan Alat Penelitian}

Obyek penelitian adalah kegiatan penebangan pohon yang merupakan salah satu rangkaian kegiatan dari pemanenan. Berdasarkan pengamatan pendahuluan di lapangan, ternyata bahwa masalah di bidang penebangan adalah masih tingginya tunggak pohon yang ditinggalkan, yaitu sekitar $20-40 \mathrm{~cm}$ di atas permukaan tanah. Alat penebangan yang umum digunakan adalah gergaji rantai (chainsare) tipe besar di mana panjang bilah 
berukuran $90 \mathrm{~cm}$. Oleh karena itu, alat penebangan yang digunakan dalam penelitian ini adalah gergaji rantai berukuran kecil yaitu merek Husqvarna tipe-40 (12 HP, berat $5 \mathrm{~kg}$ dan panjang bilah $40 \mathrm{~cm}$ ). Di samping itu alat-alat penelitian lainnya terdiri dari meteran untuk mengukur panjang batang kayu, phi-band untuk mengukur diameter pohon, stopwatch dan jam tangan untuk mengukur waktu, oli dan bensin untuk bahan bakar gergaji rantai serta alat tulis menulis.

\section{Prosedur Penelitian}

Data yang dikumpulkan adalah hasil penelitian yang dilakukan terhadap 100 pohon dengan perlakuan penebangan serendah mungkin. Penetapan pohon ditentukan secara purposif karena penebangan dilakukan dengan sistim tebang habis. Pengamatan ditujukan terhadap (1) waktu penebangan, mulai menebang sampai dengan memotong batang, pemotongan ujung dan cabang pohon dinyatakan dalam menit; (2) panjang dan diameter kayu untuk menghitung volume kayu yang dinyatakan dalam m3; (3) biaya penebangan meliputi biaya tetap maupun biaya tidak tetap dinyatakan dalam rupiah; (4) waktu kerja penebanag (operator chainsaw). Pengukuran waktu penebangan dilakukan dengan secara berturut-turut mengggunakan stopwatch dengan mencatat setiap unsur kerja.

\section{Pengolahan Data}

Pengolahan data dilakukan dengan analisis rata-rata dan statistika parametric, yang meliputi analisis data volume kayu, produktivitas penebangan dan biaya penebangan (biaya penyusutan, biaya bunga modal, biaya asuransi, biaya perawatan, biaya bahan bakar biaya oli dan pelumas, upah tenaga kerja).

Volume kayu dapat dihitung dengan rumus :

$\mathrm{V}=1 / 4 \pi(\underline{\mathrm{D}+\mathrm{d}})^{2} \times \mathrm{L}$, dimana $: \mathrm{V}=$ volume kayu $\left(\mathrm{m}^{3}\right) ; \mathrm{D}=$ diameter pangkal $(\mathrm{m})$;

$2 \mathrm{~d}=$ diameter bagian ujung $(\mathrm{m}) ; \mathrm{L}=$ panjang kayu $(\mathrm{m})$.

Produktivitas penebangan dihitung sebagai berikut :

$\mathrm{Pt}=\mathrm{Vt} / \mathrm{Wt}$

di mana: $\mathrm{Pt}=$ produktivitas penebangan $\left(\mathrm{m}^{3} / \mathrm{jam}\right) ; \mathrm{Vt}=$ volume kayu yang ditebang $\left(\mathrm{m}^{3}\right)$;

$\mathrm{W} \mathrm{t}=$ waktu kerja penebangan (jam) .

Biaya penyusutan dihitung dengan rumus :

$\mathrm{D}=\frac{\mathrm{M}-\mathrm{R}}{\mathrm{N} \times \mathrm{T}}$,

di mana : $\mathrm{D}=$ penyusutan $(\mathrm{Rp} / \mathrm{jam}) ; \mathrm{M}=$ investasi alat $(\mathrm{Rp}) ; \mathrm{R}=$ nilai alat bekas $(10 \%$ dari harga baru dalam rupiah); $\mathrm{N}=$ umur pakai alat (tahun) dan $\mathrm{t}=$ waktu kerja alat (jam/tahun). 
Untuk menghitung biaya bunga modal digunakan rumus :

$B=\frac{\{(M R)(N+1) / 2+R\} \times 0,0 p}{t}$

di mana : $\mathrm{B}=$ bunga modal (Rp/jam); $\mathrm{M}=$ harga alat $(\mathrm{Rp}) ; \mathrm{N}=$ umur pakai alat (tahun); $\mathrm{R}=$ nilai alat bekas ( $10 \%$ dari harga baru dalam rupiah): $0,0 \mathrm{p}=$ suku bunga bank per tahun (\% per tahun); $\mathrm{t}=$ waktu kerja alat (jam/tahun)

Biaya asuransi dihitung dengan rumus sebagai berikut :

$A=\frac{M \times(1+N)}{N} \times \frac{1}{t}$,

di mana : $\mathrm{A}=$ biaya asuransi $(\mathrm{Rp} / \mathrm{jam}) ; \mathrm{M}=$ harga alat $(\mathrm{Rp}) ; 1=$ nilai asuransi per dalam decimal; $N$ = umur pakai alat (tahun); $t=$ waktu kerja (jam/tahun).

Biaya perawatan dihitung dengan rumus (FAO, 1974):

Biaya perawatan $=\frac{\text { Harga alat }(\mathrm{Rp}) \times 0,1}{1.000 \mathrm{jam}}$

Biaya bahan bakar dihitung sebagai berikut :

Biaya bahan bakar $(\mathrm{Rp} / \mathrm{jam})=$ Penggunaan bahan bakar (liter/jam) $\times$ Harga bahan bakar (Rp/liter).

Biaya oli dan pelumas dihitung sebagaiberikut $(\mathrm{FAO}, 1974)$ :

Biaya oli dan pelumas $(\mathrm{Rp} / \mathrm{jam})=\{$ Harga alat $(\mathrm{Rp}) \times 0,005\} / 1.000$ jam.

Biaya penebangan dihitung sebagai berikut :

$B t=\frac{B p t+B b a t+B r t+B b t+B u t}{P t}$

di mana : $\mathrm{Bt}=$ biaya penebangan $\left(\mathrm{Rp} / \mathrm{m}^{3}\right) ; \mathrm{Bpt}=$ biaya penyusutan alat penebangan $(\mathrm{Rp} / \mathrm{jam}) ; \mathrm{Bbat}=$ biaya bunga modal, pajak dan asuransi alat penebangan $(\mathrm{Rp} / \mathrm{jam}) ; \mathrm{Brt}=$ biaya perawatan alat penebangan $(\mathrm{Rp} / \mathrm{jam}) ; \mathrm{Bbt}=$ biaya bahan bahan bakar alat penebangan $(\mathrm{Rp} / \mathrm{jam}) ;$ But $=$ biaya upah penebangan $(\mathrm{Rp} / \mathrm{jam})$ dan $\mathrm{Pt}=$ produktifitas penebangan $\left(\mathrm{m}^{3} / \mathrm{jam}\right)$. 


\section{HASIL DAN PEMBAHASAN}

Penebangan dilakukan dengan menggunakan gergaji rantai berukuran kecil (panjang bilah $40 \mathrm{~cm}$ ) merek Husqvarna tipe-40, buatan Swedia. Jenis pohon yang ditebang adalah mangium (Acacia mangium) sebanyak 97 pohon, sesuai dengan situasi dan kondisi di lapangan. Hasil pengamatan dan perhitungan volume kayu, waktu, produktivitas dan biaya penebangan dapat dilihat dalam Tabel 1. Total volume kayu yang ditebang berkisar antara $0,08-0,68 \mathrm{~m}^{3}$ per pohon dengan rata-rata total $0,25 \mathrm{~m}^{3}$ per pohon. Waktu penebangan yang dibutuhkan berkisar antara 1,06-28,75 menit per pohon atau 0,01-0,48 jam per pohon. Dengan demikian produktivitas penebangan dengan gergaji rantai berukuran kecil adalah berkisar antara $0,502-11,645 \mathrm{~m}^{3} / \mathrm{jam}$ atau rata-rata $3,112 \mathrm{~m}^{3} / \mathrm{jam}$. Variasi produktivitas penebangan tersebut cukup besar, hal ini antara lain dipengaruhi oleh diameter pohon yang ditebang, keadaan cuaca (angin), teknik penebangan (pembuatan takik rebah, takik balas) dan kedudukan pohon berdiri. Apabila terjadi hambatan dalam penebangan maka waktu tebang akan meningkat yang mengakibatkan produktivitas menjadi rendah.

Dengan diketahui harga gergaji rantai sebesar Rp 4.500.000.-, umur pakai 10.000 jam, harga bahan bakar Rp 2.000/liter, oli/pelumas Rp 550/liter; upah operator Rp 30.000.dan upah pembantu operator Rp 15.000 per hari dengan rata-rata 7 jam kerja per hari, maka biaya penebangan dapat dihitung. Sebagaimana diketahui bahwa bahan bakar gergaji mesin adalah campuran bensin dengan oli dengan perbandingan $10: 1$, di samping itu diperlukan juga pelumas/oli untuk rantai gergaji. Berdasarkan data di atas dapat dihitung unsur-unsur biaya penebangan sebagai berikut : biaya penyusutan $=R p 405 /$ jam, pemeliharaan $=\mathrm{Rp} 405 / \mathrm{jam}$, pajak, asuransi dan bunga $=\mathrm{Rp} 243 / \mathrm{jam}$, bahan bakar $=\mathrm{Rp} 2.000 / \mathrm{jam}$, upah operator dan pembantu $=\mathrm{Rp} 6.428 / \mathrm{jam}$, sehingga besarnya biaya penebangan per jam $=\mathrm{Rp}$ 9.481. Dengan demikian biaya penebangan berkisar antara $R p 814 / \mathrm{m}^{3}$ - Rp 18.866/m3 dengan rata-rata $\mathrm{Rp} 4.411 / \mathrm{m}^{3}$ (Tabel 1).

Tabel 1. Volume kayu $\left(\mathrm{m}^{3}\right)$, waktu penebangan (menit) dan produktivitas $\left(\mathrm{m}^{3} / \mathrm{jam}\right)$ Table 1. Wood volume $\left(\mathrm{m}^{3}\right)$, felling time (minute) and productivity $\left(\mathrm{m}^{3} / \mathrm{bour}\right)$

\begin{tabular}{|c|c|c|c|c|}
\hline No & $\begin{array}{c}\text { Volume kayu/ } \\
\text { Wood volume } \\
\left(\mathrm{m}^{3}\right)\end{array}$ & $\begin{array}{c}\text { Waktu penebang } \\
(\text { menit}) / \text { Felling } \\
\text { time (minute })\end{array}$ & $\begin{array}{c}\text { Produktivitas } \\
\left(\mathrm{m}^{3} / \text { jam }\right) / \text { Productivity } \\
\left(\mathrm{m}^{3} / \text { hour }\right)\end{array}$ & $\begin{array}{c}\text { Biaya }\left(\mathrm{Rp} / \mathrm{m}^{3}\right) \\
\text { Cost }\left(\mathrm{Rp} / \mathrm{m}^{3}\right)\end{array}$ \\
\hline 1 & 0,1794 & 11,83 & 0,9101 & $10.417,99$ \\
\hline 2 & 0,0523 & 6,25 & 0,5025 & $18.866,05$ \\
\hline 3 & 0,0900 & 4,33 & 1,2465 & $7.605,87$ \\
\hline 4 & 0,5726 & 17,04 & 2,0162 & $4.702,34$ \\
\hline 5 & 0,1200 & 6,83 & 1,0542 & $8.993,92$ \\
\hline 6 & 0,1876 & 5,28 & 2,1324 & $4.446,23$ \\
\hline 7 & 0,0631 & 5,13 & 0,7385 & $12.838,54$ \\
\hline 8 & 0,6767 & 10,26 & 3,9571 & $2.395,96$ \\
\hline 9 & 0,1641 & 6,40 & 1,5380 & $6.164,58$ \\
\hline 10 & 0,3860 & 15,73 & 1,4724 & $6.439,26$ \\
\hline
\end{tabular}




\begin{tabular}{|c|c|c|c|c|}
\hline 11 & 0,2207 & 8,48 & 1,5613 & $6.072,39$ \\
\hline 12 & 0,1369 & 8,40 & 0,9779 & $9.694,93$ \\
\hline 13 & 0,3463 & 14,75 & 1,4087 & $6.730,35$ \\
\hline 14 & 0,1289 & 5,35 & 1,4451 & $6.560,67$ \\
\hline 15 & 0,1818 & 4,11 & 2,6536 & $3.572,93$ \\
\hline 16 & 0,2208 & 6,61 & 2,0045 & $4.729,86$ \\
\hline 17 & 0,7390 & 11,13 & 3,9838 & $2.379,89$ \\
\hline 18 & 0,1395 & 4,43 & 1,8892 & $5.018,46$ \\
\hline 19 & 0,1013 & 6,21 & 0,9789 & $9.685,57$ \\
\hline 20 & 0,2102 & 4,13 & 3,0537 & $3.104,73$ \\
\hline 21 & 0,1794 & 6,75 & 1,5950 & $5.944,33$ \\
\hline 22 & 0,2109 & 10,75 & 1,1770 & $8.055,09$ \\
\hline 23 & 0,2386 & 13,83 & 1,0353 & $9.158,09$ \\
\hline 24 & 0,3577 & 10,91 & 1,9672 & $4.819,58$ \\
\hline 25 & 0,1965 & 6,70 & 1,7598 & $5.387,65$ \\
\hline 26 & 0,1711 & 3,98 & 2,5794 & $3.675,71$ \\
\hline 27 & 0,1181 & 2,65 & 2,6732 & $3.546,71$ \\
\hline 28 & 0,1993 & 2,20 & 5,4345 & $1.744,59$ \\
\hline 29 & 0,1470 & 1,18 & 7,4734 & $1.268,63$ \\
\hline 30 & 0,4389 & 28,75 & 0,9160 & $10.350,37$ \\
\hline 31 & 0,2373 & 4,33 & 3,2888 & $2.882,85$ \\
\hline 32 & 0,2729 & 15,35 & 1,0668 & $8.886,92$ \\
\hline 33 & 0,3463 & 12,80 & 1,6234 & $5.840,24$ \\
\hline 34 & 0,2581 & 8,11 & 1,9096 & $4.964,86$ \\
\hline 35 & 0,2489 & 9,25 & 1,6142 & $5.873,51$ \\
\hline 36 & 0,2708 & 22,28 & 7,1253 & $1.330,61$ \\
\hline 37 & 0,2450 & 1,71 & 8,5961 & $1.102,94$ \\
\hline 38 & 0,0852 & 0,66 & 7,7461 & $1.223,98$ \\
\hline 39 & 0,3392 & 6,53 & 3,1168 & $3.041,86$ \\
\hline 40 & 0,2683 & 6,25 & 2,5761 & $3.680,35$ \\
\hline 41 & 0,1355 & 1,50 & 5,4184 & $1.749,76$ \\
\hline 42 & 0,2278 & 4,05 & 3,3747 & $2.809,40$ \\
\hline 43 & 0,1489 & 5,61 & 1,5296 & $5.953,06$ \\
\hline 44 & 0,2348 & 1,21 & 11,6451 & 814,16 \\
\hline 45 & 0,8152 & 12,78 & 3,8271 & $2.477,30$ \\
\hline 46 & 0,2205 & 4,50 & 2,9401 & $3.224,73$ \\
\hline 47 & 0,6287 & 10,25 & 3,6803 & $2.576,13$ \\
\hline 48 & 0,3624 & 6,30 & 3,4515 & $2.746,90$ \\
\hline 49 & 0,1809 & 2,30 & 2,8405 & $3.337,84$ \\
\hline 50 & 0,1278 & 4,26 & 1,8001 & $5.266,80$ \\
\hline 51 & 0,7248 & 13,16 & 3,3047 & $2.868,98$ \\
\hline 52 & 0,2650 & 2,95 & 5,3907 & $1.758,77$ \\
\hline
\end{tabular}


jURNAL Penelitian Hasil Hutan Vol. 23 No. 1, Februari 2005: 69-78

\begin{tabular}{|c|c|c|c|c|}
\hline 53 & 0,3457 & 8,45 & 2,4545 & $3.862,66$ \\
\hline 54 & 0,2632 & 6,05 & 2,6102 & $3.632,35$ \\
\hline 55 & 0,6569 & 11,20 & 3,5193 & $2.694,03$ \\
\hline 56 & 0,2642 & 2,80 & 5,6605 & $1.674,94$ \\
\hline 57 & 0,1805 & 2,80 & 3,8674 & $2.451,49$ \\
\hline 58 & 0,4152 & 8,71 & 2,8605 & $3.314,51$ \\
\hline 59 & 0,2618 & 4,85 & 3,2390 & $2.927,11$ \\
\hline 60 & 0,3408 & 6,83 & 2,9943 & $3.166,39$ \\
\hline 61 & 0,0780 & 2,30 & 2,0337 & $4.661,94$ \\
\hline 62 & 0,1131 & 3,53 & 1,9226 & $4.931,31$ \\
\hline 63 & 0,3423 & 12.06 & 1,7029 & $5.567,66$ \\
\hline 64 & 0,3519 & 5,11 & 4,1314 & $2.294,84$ \\
\hline 65 & 0,1172 & 4,56 & 2,3318 & $4.065,91$ \\
\hline 66 & 0,2166 & 6,83 & 1,9031 & $4.981,76$ \\
\hline 67 & 0,1465 & 2,76 & 3,1847 & $2,977,08$ \\
\hline 68 & 0,1839 & 2,36 & 4,6765 & $2.027,36$ \\
\hline 69 & 0,1781 & 4,45 & 2,4009 & $3.948,99$ \\
\hline 70 & 0,2960 & 4,51 & 3,9375 & $2.407,87$ \\
\hline 71 & 0,1710 & 5,13 & 1,9997 & $4.741,13$ \\
\hline 72 & 0,2912 & 6,20 & 2,8182 & $3.364,17$ \\
\hline 73 & 0,1743 & 4,83 & 2,1655 & $4.378,28$ \\
\hline 74 & 0,0291 & 1,23 & 1,4182 & $6.685,17$ \\
\hline 75 & 0,1585 & 3,05 & 3,1179 & $3.040,81$ \\
\hline 76 & 0,1089 & 2,51 & 2,6028 & $3.642,60$ \\
\hline 77 & 0,1113 & 3,96 & 1,6864 & $5.622,14$ \\
\hline 78 & 0,2229 & 3,93 & 3,4034 & $2.785,74$ \\
\hline 79 & 0,3416 & 4,61 & 4,4464 & $2.132,28$ \\
\hline 80 & 0,2288 & 7,16 & 1,9173 & $4.944,88$ \\
\hline 81 & 0,2341 & 5,40 & 2,6013 & $3.644,71$ \\
\hline 82 & 0,3741 & 2,66 & 8,4381 & $1.123,60$ \\
\hline 83 & 0,2376 & 2,66 & 5,3599 & $1.768,89$ \\
\hline 84 & 0,1618 & 5,71 & 1,7001 & $5.576,61$ \\
\hline 85 & 0,1329 & 2,08 & 3,8332 & $2.473,40$ \\
\hline 86 & 0,1974 & 1,16 & 10,2100 & 928,60 \\
\hline 87 & 0,2094 & 4,95 & 2,5381 & $3.735,48$ \\
\hline 88 & 0,1113 & 2,75 & 2,4284 & $3.904,26$ \\
\hline 89 & 0,2213 & 4,50 & 2,9508 & $3.213,00$ \\
\hline 90 & 0,0928 & 7,20 & 0,7731 & $12.262,93$ \\
\hline 91 & 0,2092 & 5,31 & 2,3642 & $4.010,23$ \\
\hline 92 & 0,2560 & 4,13 & 3,7195 & $2.549,02$ \\
\hline 93 & 0,1250 & 1,06 & 7,0750 & $1.340,07$ \\
\hline 94 & 0,0852 & 1,35 & 3,7870 & $2.503,59$ \\
\hline
\end{tabular}




\begin{tabular}{|c|r|r|r|r|}
\hline 95 & 0,4759 & 6,02 & 4,7430 & $1.998,93$ \\
\hline 96 & 0,3080 & 3,41 & 5,4188 & $1.749,65$ \\
\hline 97 & 0,4118 & 8,71 & 2,8366 & $3.342,39$ \\
\hline $\begin{array}{c}\text { Jumlah } \\
(\text { Sum })\end{array}$ & 24,2400 & 598,35 & 301,8482 & $427.834,05$ \\
\hline $\begin{array}{c}\text { Rata-rata } \\
(\text { Average })\end{array}$ & 0,2499 & 6,17 & 3,1118 & $4.410,66$ \\
\hline
\end{tabular}

Dari Tabel 1 dapat dilihat bahwa biaya penebangan berkisar antara Rp 814 $\mathrm{Rp} 18.866 / \mathrm{m}^{3}$ dengan rata-rata $\mathrm{Rp} 4.411 / \mathrm{m}^{3}$. Variasi biaya penebangan tersebut cukup besar sebagai akibat dari variasi produktivitas yang cukup besar, sehingga untuk menekan biaya penebangan serendah mungkin, produktivitas penebangan harus ditingkatkan antara lain dengan mengurangi waktu kerja persiapan, tebang pohon dan pembagian batang.

Dari hasil di atas ada beberapa keuntungan penebangan dengan gergaji rantai berkuruan kecil, antara lain : (1) Menghemat tenaga kerja dalam transportasi dan pengoperasiannya; (2) Memudahkan dalam membuat takik rebah dan takik balas; (3) Dapat menebang pohon serendah mungkin, karena gergaji rantai lebih ringan; (4) Biaya pemilikan lebih murah; (5) Untuk kayu berdiameter kecil, biaya operasional relatif lebih murah; (6) Gerakan berpindah tempat dari pohon ke pohon lebih cepat dan (7) Biaya pemeliharaan lebih rendah.

Di samping itu ada beberapa kerugian dengan menggunakan gergaji rantai yang berukuran kecil, antara lain : (1) Kurang efisien untuk menebang pohon yang berdiameter besar; (2) Mempunyai tenaga relatif lebih kecil; (3) Para penebangan (operator) relative belum berpengalaman menggunakan gergaji rantai yang berukuran kecil.

\section{KESIMPULAN DAN SARAN}

Dari hasil dan pembahasan terdapat beberapa kesimpulan dan saran sebagai berikut:

1. Jenis pohon yang ditebang di areal tebang habis hutan tanaman industri PT Inhutani II di Palau Laut adalah mangium (Acacia mangium). Produktivitas penebangan dengan gergaji rantai tipe 40 (ukuran bilah kecil $=40 \mathrm{~cm}$ ) merek Husqvarna berkisar $0,738-11,645 \mathrm{~m}^{3} /$ jam dengan rata-rata $3,12 \mathrm{~m}^{3} /$ jam.

2. Biaya penebangan berkisar antara $R p 814-R p 18.866 / \mathrm{m}^{3}$ dengan rata-rata $\mathrm{Rp} 4.411$ per $\mathrm{m}^{3}$.

3. Penggunaan gergaji rantai berukuran kecil untuk penebangan pohon dengan diameter kecil seperti di hutan tanaman industri cukup efisien.

4. Dalam pengembangan penggunaan gergaji rantai berukuran kecil harus dibarengi dengan peningkatan keterampilan tenaga kerja penebang. 


\section{DAFTAR PUSTAKA}

FAO. 1974. Logging and log transportation in tropical high forest. Forestry Development Paper No. 18. Rome

Sastrodimedjo, S. dan S.R. Simarmata. 1978. Limbah eksploitasi pada beberapa perusahaan hutan di Indonesia. Laporan Lembaga Penelitian Hasil Hutan No. 20 Bogor.

Sinaga, M. dan J. Thaib. 1982. Limbah eksploitasi hutan payau pada beberapa perusahaan pengusahaan hutan di Indonesia. Laporan Balai Penelitian Hasil Hutan, No. 159. Bogor.

Simarmata, S.R. dan Dulsalam. 1985a. Volume dan klasifikasi limbah penebangan pada beberapa perusahaan hutan di Aceh dan Kalimantan Timur. Jurnal Penelitian Hasil Hutan 2(12) : 17-19.

. 1985b. Limbah eksploitasi pada beberapa perusahaan pengusahaan hutan di Kalimantan dan Sumatera. Lembaran Penelitian Pusat Penelitian dan Pengembangan Hasil Hutan, No. 20.

Staaf, K.A.G. \& N.A. Wiksten. 1984 Tree Harvesting Techniques. Martinus Nijhoff/Dr. W.Junk Publisher. Dordrecht/Lancaster. 